\title{
An analysis of the effects of supply chain risk management on resilience to economic risk. A case of Pharmaceutical retailers in Zimbabwe
}

\author{
Dumisani Mawonde, Casper Demberere and Regis Muchowe \\ Bindura University of Science Education, Zimbabwe
}

\begin{abstract}
This study has analysed of supply chain risk management on resilience to economic risk in pharmaceutical retailers in Zimbabwe. A mixed method research approach was adopted in the form of descriptive research design and data was collected using questionnaires and interviews. The IBM SPSS version 16 software was used to analyse quantitative data whilst thematic analysis was used to analyse qualitative data. A total of 100 questionnaires were sent to pharmaceutical retailing firms and 92 questionnaires were completed and returned to the researcher on time and were used for data analysis. Face to face interviews were successfully conducted with 10 key informants in pharmaceutical retailing firms. The findings of the study show that supply chain risk management had a significant positive effect on resilience to economic risks. The study concluded that supply chain risk management helps pharmaceutical retailers to be resilient to economic risks. Therefore, it was recommended that pharmaceutical retailers must adopt supply chain risk management strategies such as risk identification, risk planning, risk avoidance and risk pooling in order to be resilient to economic risks.
\end{abstract}

Key words: supply chain, risk, economic risk, Resilience.

\section{INTRODUCTION}

$\mathrm{T}$ he practice of supply chain risk management is key in protecting firms from the damaging effects of supply chain disruptions. Because of the uncertainties in supply chains across the globe, the concept of supply chain risk management has received more attention from many supply chain practitioners in many firms worldwide (Leat and Revoredo-Giha, 2013). Supply chain risks affect the operations of firms worldwide that firms must embrace risk management strategies to survive in a competitive business environment (Dickson and Önsel, 2017). These risks include; economic risk, social risk, political risk, technological risk, legal risk, operational risks and environmental risks.

In Zimbabwe, retail pharmaceutical firms are mostly vulnerable to economic risks which affect their operations and make it difficult for them to meet the requirements of customers. The economic risks that affect the operations of retail pharmaceutical firms in Zimbabwe include, unstable exchange rates, shortage of foreign currency, high bank charges and high bank interest rates. These risks affect the pharmaceutical supply chains and the ease of doing business in the retail pharmaceutical sector.
More so, the supply chain disruptions that are caused by economic risks have been causing an immense decline in sales in retail pharmaceutical companies and this is reducing their profitability. Therefore, this encouraged the researchers to carry out a study to examine the effects of supply chain risk management strategies on resilience to supply chain economic risks in the retail pharmaceutical sector in Zimbabwe.

\section{LITERATURE REVIEW}

This section reviews the literature related to the study. The section defines supply chain risk, explains supply chain risk management strategies and it also provides he conceptual framework which shows the independent and dependent variables in this study.

\subsection{Supply chain risk}

Supply chain risk is the variation in the distribution of possible supply chain outcomes, their likelihood, and their subjective values. On the other hand, Peck (2006) defines supply chain risks as anything that disrupts or impedes the information, material as material or product flows from original suppliers to the delivery of the final product to the ultimate end user.

\subsection{Economic risk}

Pharmaceutical retailing firms in Zimbabwe are susceptible to the economic risk of exchange rate fluctuations. Exchange rate fluctuations are medium-term to long-term in nature. These exchange rate fluctuations are usually unpredicted that they expose pharmaceutical retail firms to the risk of losses as they affect the company's cash flows and market value. Also, Copeland (2008) put forward that unanticipated exchange rate fluctuations can have a huge effect on the competitive position of a firm in the environment it operates in.

A shift in government economic policy is another supply chain risk that affects the operations of pharmaceutical retail firms. A government policy is a plan or course of action which is intended to influence and determine decisions, actions, and other matters (Sum, 2012). A change in economic policy affects the banking sector causing interest rates and bank charges to change and this affects the business of pharmaceutical retail firms. Therefore, this also affects the 
business of players in the pharmaceutical supply chains and eventually the operations of pharmaceutical retail firms.

Furthermore, the change in currency is another form of economic risk that affects the business of pharmaceutical retail firms. According to Gilmore (2014) change in currency that is used in a country is a risk in a firm's equity. As exchange rate fluctuations in a country are mostly unpredictable, there is always a risk of change in currency used and this affects the business of firms.

\subsection{Supply chain risk management strategies}

According to Baryannis, Validi, Dani, and Antoniou (2019), supply chain risk management strategies include risk identification, risk planning, risk avoidance and risk pooling:

Firstly, supply chain risk identification techniques are established methods of analysing project information and discovering threats and opportunities (Ziegenbein, 2007). In supply chain risk management, the most popular techniques which are used are brainstorming, interviews, document analysis, checklists, root cause analysis and assumptions analysis. The objective of the supply chain risk management strategy is to ensure that all potential project risks are identified.

Secondly, risk planning is another supply chain risk management strategy that is used by firms. Agrawal, De Meyer, and Van Wassenhove (2014) posit that risk planning involves preparing for the most important supply chain risk events in advance, prioritizing them, and developing the appropriate supply chain risk response plans. It includes establishing objectives, determining investment style, evaluating investments, choosing an appropriate investment plan, executing and periodically examining the plan. Also, it allows the organisation to prepare for the unexpected, minimizing supply chain risks and extra costs before they happen.

The third strategy is risk avoidance and this strategy seeks to avoid compromising events entirely. Aigbogun, Ghazali, and Razali, (2014) states that risk avoidance is the elimination of hazards, activities, and exposures that can negatively affect an organization's assets. The strategy adjusts the project to try to make sure that the risk is eliminated. The exposure to supply chain risks is not permitted to come into existence at all. This is accomplished by simply not engaging in the action that gives rise to any form of supply chain risks.

Lastly, risk pooling is another strategy. Risk pooling is an important concept in supply chain risk management which is the practice of sharing all risks in a supply chain. This process can be used effectively to transfer organisational risks to the supply chain players. According to Bai and Sarkis (2012) under this system, supply chain companies come together to form a pool, which can provide protection to companies in a supply chain against all supply chain risks.

\subsection{Conceptual Framew ork}

This study was guided by the following conceptual framework.

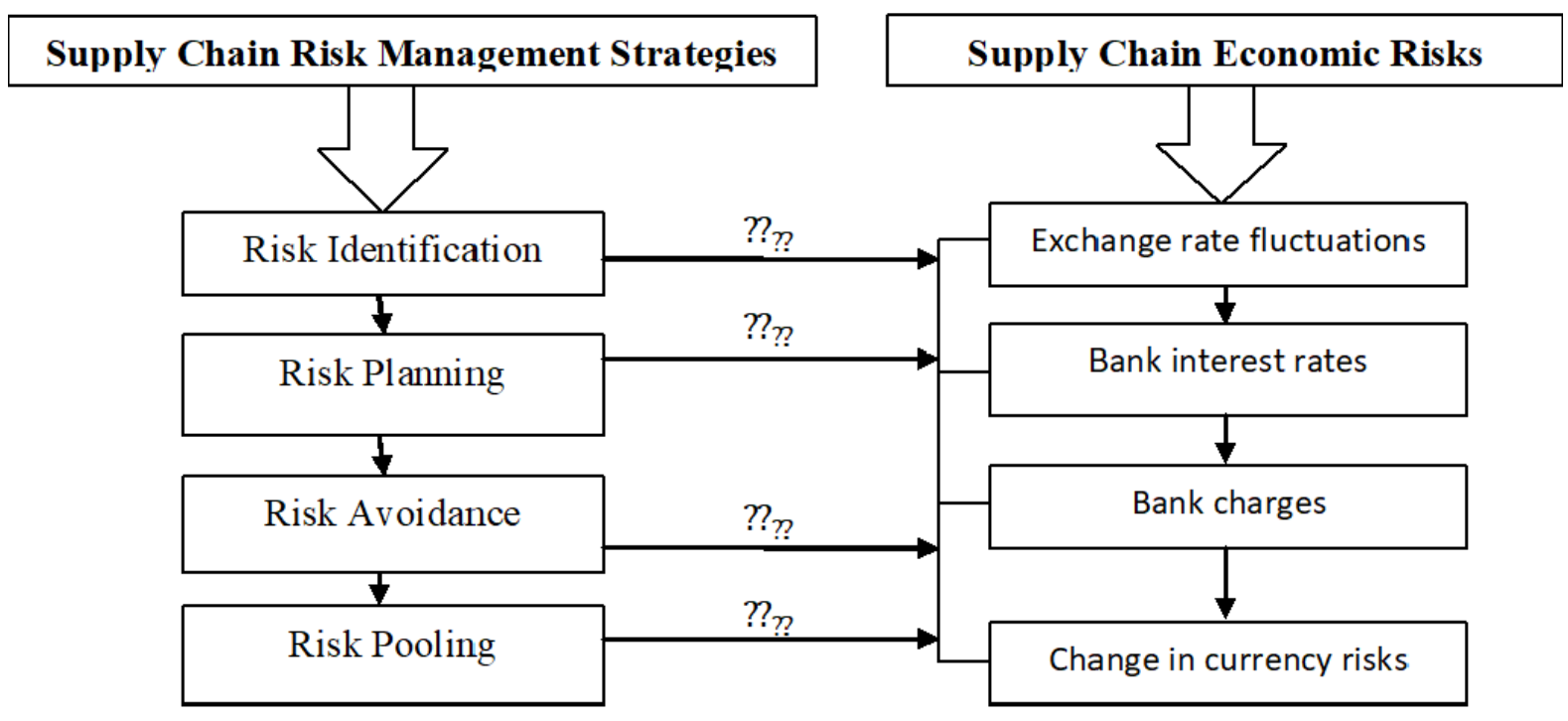

Source: Authors (2021) 


\section{RESEARCH METHODOLOGY}

A mixed method research approach was adopted in the form of descriptive research design. Descriptive research design was used to allow researchers to view perceptions, attitudes and behaviours of employees pertaining to the effects of supply chain risk management strategies on resilience of supply chain economic risks in the Zimbabwean retail pharmaceutical industry (Heale and Twycross, 2015).

The study targeted a population composed of 120 supply chain employees working in retail pharmacies in Zimbabwe and a sample size of 92 supply chain professionals working in pharmaceutical firms was chosen using the Krejcie and Morgan (1970) formula. A purposive sampling technique was used to collect data from supply chain departments of retail pharmacies because they are involved with the retail pharmaceutical purchasing of organizational requirements. Questionnaires were used to collect quantitative data and qualitative data was collected through face to face and telephone interviews.

\section{RESULTS AND THEIR DISCUSSION.}

This section presents, interprets and discusses the findings of this study. Table 4.1 below shows the multiple linear regression coefficients which show the results on the impact of supply chain risk management on resilience to economic risks.

Table 4.1: Multiple Linear Regression Coefficients

\begin{tabular}{|c|c|c|c|c|c|c|}
\hline \multirow{2}{*}{\multicolumn{2}{|c|}{$\begin{array}{c}\text { Supply Chain Risk } \\
\text { Management } \\
\text { Strategies }\end{array}$}} & \multicolumn{2}{|c|}{$\begin{array}{l}\text { Unstandardized } \\
\text { Coefficients }\end{array}$} & \multirow{2}{*}{$\begin{array}{c}\begin{array}{c}\text { Standar } \\
\text { dized } \\
\text { Coeffici } \\
\text { ents }\end{array} \\
\text { Beta }\end{array}$} & \multirow[t]{2}{*}{$\mathrm{T}$} & \multirow[t]{2}{*}{ Sig. } \\
\hline & & B & $\begin{array}{l}\text { Std. } \\
\text { Error }\end{array}$ & & & \\
\hline \multirow{5}{*}{1} & (Constant) & .250 & .327 & & .762 & .448 \\
\hline & $\begin{array}{c}\text { Risk } \\
\text { identification }\end{array}$ & 136 & .051 & .188. & 2.651 & .010 \\
\hline & Risk planning & 191 & .085 & .178 & 2.234 & .028 \\
\hline & $\begin{array}{c}\text { Risk } \\
\text { avoidance }\end{array}$ & .575 & .085 & .585 & 6.738 & .000 \\
\hline & Risk pooling & .021 & .061 & .022 & .337 & .073 \\
\hline \multicolumn{7}{|c|}{$\begin{array}{c}\text { a. Dependent Variable: Resilience to Economic Risk } \\
\text { n=92, Source: Primary Data (2021) } \\
\text { IBM SPSSv16 }\end{array}$} \\
\hline
\end{tabular}

Table 4.1 above shows that risk identification has a positive and significant impact on resilience to economic risks with a ( $p$ value of $0.010(p<0.05)$ and beta value of 0.136 ). This implies that risk identification impacts positively on resilience to economic risks. This result agrees with the interview results that risk identification positively impacts resilience to economic risks. The results also agree with the findings in a study by Musa (2012) that risk identification improves supply chain performance in firms.

The results also show that, risk planning strategy has a statistically significant relationship (beta value of 0.191 , and $\mathrm{p}$ value of $0.28(\mathrm{p}<0.05)$. with resilience to economic risks.
This implies that the more the risk planning strategy is in place, the more resilient a firm is to economic risks. The results were corroborate with the interview findings that risk planning strategy encourages a firm to look into its threats. The findings of this study agree with the findings in a study by Lee and Ulferts (2011), risk planning in supply chain management provides firms with competitive advantage and future survival.

Furthermore, table 4.1 shows that risk avoidance has a positive and significant impact on resilience to economic risks (beta value of 0.575 , and $p$ value of $p<0.00$ ). This shows the importance of risk avoidance in resilience to economic risks and it implies that the more pharmaceutical retailers implement the risk avoidance strategy, the more they become resilient to economic risks. This agrees with findings from the interview responses that pharmaceutical retailers have been practicing risk avoidance through policy and procedures, implementation of technologies, as well as training and education to supply chain professionals. The findings agree with the findings in a study by Beetge et al., (2019) that risk avoidance plays a significant role in mitigating supply chain risks.

Finally, table 4.1 shows that risk pooling has a positive and significant impact on resilience to economic risk $(p<$ value of $0.073(\mathrm{p}<0.1)$ and beta 0.021$)$. This implies that risk pooling positively and significantly impacts resilience to economic risks. This agrees with the interview findings that risk-pooling helps firms to be resilient to economic risks. This also corroborates with the findings in a study by Kutzin et al (2019) who found out that risk pooling helps companies to address supply chain risk problems.

\section{CONCLUSIONS AND RECOMMENDATIONS}

Based on the results presented, it can be concluded that supply chain risk management strategies such as risk identification, risk planning, risk avoidance and risk pooling have a positive and significant effect on resilience to economic risks of pharmaceutical retailers in Zimbabwe. Therefore, it can be concluded that supply chain risk management helps pharmaceutical retailers to be resilient to economic risks. In view of this, the researchers recommend pharmaceutical retailers to adopt supply chain risk management strategies such as risk identification, risk planning, risk avoidance and risk pooling buy in order to be resilient to economic risks.

\section{ACKNOWLEDGEMENT}

The writers of this paper would like to thank the employees working in pharmaceutical retail firms in Zimbabwe for completing the questionnaires and for responding to face to face and telephone interviews during the data collection process. Their participation and responses went a long way in making this study a success. Moreover, a big thank you goes to Dr Felix Chari, a Bindura University of Science Education lecturer for his supervision in writing this paper. Without his 
supervision, it would have been very difficult to write this paper.

\section{REFERENCES}

[1] Agrawal, A., De Meyer, A., and Van Wassenhove, L. N. (2014) Managing value in supply chains: Case studies on the sourcing hub concept. California Management Review 56(2), 23-54. doi:10.1525/cmr.2014.56.2.23

[2] Aigbogun, O., Ghazali, Z., and Razali, R. (2014). A framework to enhance supply chain resilience: The case of Malaysian pharmaceutical industry. Global Business \& Management Research, 6, 219-228. Retrieved from http://www.gbmr.ioksp.com

[3] Bai, C., and Sarkis, J. (2012). Supply-chain performancemeasurement system management using neighborhood rough sets. International Journal of Production Research, 50, 2484-2500. doi:10.1080/00207543.2011.581010

[4] Baryannis., G., Validi., S., Dani., S., Antoniou., G., (2019). Supply chain risk management and artificial intelligence: state of the art and future research directions. International Journal of Production Research, Vol. 57, (7), pp: 2179 - 2202. doi.org/10.1080/00207543.2018.1530476

[5] Celly, K.S., Frazier, G.L., 1996. Outcome-based and behaviorbased coordination efforts in channel relationships. Journal of Marketing Research 33 (2), 200-210.

[6] Gilmore. S., (2014). Local currency bonds needed to fill Asia's infrastructure financing gap. Emerging Markets. Retrieved from http://www. emergingmarkets.org/Article/3337340/Local currency-bonds-needed-to-fill-Asias-infrastructure-financinggap.html

[7] Heale, R., and Twycross, A., (2015). Research made simple: End of Life Journal. Retrieved from http://ebn.bmj.com/content/early on 15 January 2017

[8] Krejcie V.R and Morgan W.D (1970). "Determining Sample Size for Research Activities". The NEA Research Bulletin, Vol. 38, pp 99.

[9] Lee, C., and Ulferts, G. (2011). Managing Supply Chain Risks and Risk Mitigation Strategies. North Korean Review, Vol 7 (2), pp: 34-44.

[10] March JG, Shapira Z. Managerial perspectives on risk and risk taking. Management Science 1987; 33(11):1404-18
[11] Meyer, A., Niemann, W., Uys, G. and Beetge, D., (2019), an exploration of supply chain risk management in the South African third-party logistics industry', ActaCommercii 19(1), a612. https://doi.org/10.4102/ac.v19i1.612

[12] Nurmaya Musa., S., (2012). Supply Chain Risk Management: Identification, Evaluation and Mitigation Techniques. Linköping University. Sweden

[13] Peck H. (2006). Reconciling supply chain vulnerability, risk and supply chain management. International Journal of Logistics Research and Applications 2006; 9(2):127-42.

[14] Singhal, P., Agarwal, G., and Mittal, M. L. (2011). Supply chain risk management: review, classification and future research directions. International Journal of Business Science and Applied Management, 6(3), 15-42

[15] Scholten, K., Sharkey Scott, P. and Fynes, B., (2014), 'Mitigation processes - Antecedents for building supply chain resilience', Supply Chain Management: An International Journal Vol 19 (2), pp: 211-228. https://doi.org/10.1108/SCM-062013-0191

[16] Sum. V., (2012). Economic policy uncertainty in the U.S. and Europe: A cointegration test. http://papers.ssm.com/soI3/papers.cfm?abstracUd=2074114. (Accessed 24 June 2013)

[17] Wegner, D. (2002). The Illusion of Conscious Will. MIT Press

[18] Wieland, A. and Marcus Wallenburg, C., (2012), 'Dealing with supply chain risks: Linking risk management practices and strategies to performance', International Journal of Physical Distribution and Logistics Management Vol 42 (10), pp: $887-$ 905. doi.org/10.1108/09600031211281411

[19] Zahiri, B., and M. Pishvaee. (2017). "Blood Supply Chain Network Design Considering Blood Group Compatibility Under Uncertainty.” International Journal of Production Research 55 (7): 2013-2033

[20] Zhao, L., Huo, B., Sun, L., and Zhao, X., (2013), The impact of supply chain risk on supply chain integration and company performance: a global investigation, Supply Chain Management, Vol. $18 \quad$ No. $2, \quad$ pp. 131. https://doi.org/10.1108/13598541311318773

[21] Ziegenbein, A. (2007): Supply Chain Risk - Identification, Assessment and Mitigation. vdfHochschulverlag Zürich 